\title{
Multilingual educational language policies in Switzerland and Sweden
}

\author{
A meta-analysis
}

\author{
Adrian Lundberg \\ Malmö University
}

\begin{abstract}
Multilingualism represents a global challenge and a goal of education in European states. This meta-analysis examines how research studies on multilingual educational policy documents on a macro-level (national/regional) in Sweden and Switzerland differ in terms of foci and how the discourses in the articles represent different treatments of multilingual educational language policies. These countries were selected because of their similarities regarding the societal context, but they are different in regard to language policy issues and political formation. The articles were systematically identified via two databases, ERIC and LLBA, and in order to examine the latest developments after the introduction of a new language act in Sweden and the harmonization of public education in Switzerland in 2009, only research articles published between 2009 and 2016 were included. The results of the study suggest that a monolingual habitus exists in the Swedish nation state context compared to a more pluralistic approach in Switzerland. The most noteworthy result is the diverging definitions of multilingualism and plurilingual students and how this understanding influences the treatment of educational policies in these two linguistically and culturally superdiverse European countries.
\end{abstract}

Keywords: language policy, European Union, multilingualism, plurilingualism, Sweden, Switzerland, educational language policy, curriculum

In 2009, Sweden introduced a new Language Act (2009, p.600) to protect the Swedish language by making it the official principal language in the country. The Act's different provisions to ensure that an individual is given access to language was aimed at finding strategies for balanced multilingualism. In the same year, Switzerland agreed on the harmonization of compulsory education, including the introduction of a new language curriculum based on multilingualism. The sys- 
tematic meta-analysis offered in this article therefore synthesizes research results on multilingual educational language policies from the two countries in order to identify and describe the predominant research topics during the implementation process in the years after the policy changed.

As Daryai-Hansen et al. (2015, p.110) note, "while the idea of plurilingual competence is well accepted in research on language education and promoted in language policies, it is not established in education in general." A related conclusion is arrived at by Gogolin and Duarte (2013, p. 6) who state that the notion "of a 'language' as a homogeneous and clearly defined or definable object, which can be linked to a likewise identifiable 'people' [...] may no longer be reflected in state of the art research on language phenomena." However, it prevails in the political sphere, educational practice, and as a common belief in European societies. In contrast to this ideology, sociolinguistic research shows that hundreds of millions use two or more languages without any particular difficulties, and "multilingualism is increasingly frequently seen as an emblem of identity - an essential component of European culture" (Lüdi \& Py, 2009, p. 156). According to Jessner (2008, p.27), "The application of monolingual norms to multilingual contexts is still predominant, despite the efforts of the European Union to foster plurilingualism." Gogolin's hypothesis concerning the teachers' monolingual orientation in European schools "is an intrinsic element of their professional 'habitus' as members of the nation state school system" (2013, p.42). She uses the term 'monolingual habitus' as "the deep-seated habit of assuming monolingualism as the norm in a nation" (2013, p.41). As a consequence, for these rather traditional classrooms, language subjects are often kept totally apart. Teachers with a monolingual habitus would therefore "keep knowledge about other languages, including the L1 [the students' first language], out of the classroom in order not to confuse students" (Jessner, 2008, p. 39). Also, according to Busch (2011, p. 545), "Most of the European education systems are still under the heavy influence of monolingual and homoglossic ideologies." While education systems continue to apply the construct of the monolingual habitus "displaying monolingual self conceptions in their constitutions, structures and practical arrangements" (Gogolin \& Duarte, 2013, p. 1), we live in a superdiverse society (Vertovec, 2007). The large number of refugees making their way to Europe since 2015 is only the latest development of a process that has already been in existence for several decades. Moreover, multiculturalism and multilingualism in Europe is by no means limited to refugees but "is affected by the now ubiquitous process of economic globalization and transnational activities of population mobility, wars, activism, and networking and communication technologies" (Lo Bianco \& Bal, 2016, pp.4-5).

By synthesizing research results on multilingual educational policy documents on a macro-level (national/regional) in the nation states of Sweden and 
federalist Switzerland, it is possible to contrast the predominant foci and identify the similarities and differences of these countries. The comparison is relevant, as members of the Swiss educational arena are expected to be less guided by a monolingual habitus due to the country's political and multilingual origins. While Switzerland and Sweden are different in terms of their political organization and language policy issues, their societal contexts are similar, with 8 to respectively 10 million inhabitants and around 200 languages used on a daily basis by many immigrants in both countries. Also, their Life Satisfaction Index by the OECD's Better Life Index, which measures the well-being of societies is on a comparable level with 7.3 for Sweden and 7.6 for Switzerland out of 10 (OECD, 2017).

The aims of this meta-analysis are to identify and describe published research results on multilingual educational policy documents and how the findings differ between Switzerland and Sweden regarding the treatment of these policy documents. Two research questions have been formulated in order to achieve these aims:

1. What are the predominant foci in research results on Swedish and Swiss multilingual educational policy documents?

2. Do these findings show a rather monolingual or pluralistic approach in the treatment of current educational language policies?

Sufficient information about the sociolinguistic context of the two countries and the topic of multilingualism and multiculturalism in Europe provides a clear understanding of the situation in the two selected countries. After the section on the methodology used in this article, the results of the studies are discussed. Thus, this article seeks to contribute to the understanding of different educational policy contexts connected to multicultural and multilinguistic issues.

\section{Sociolinguistic and policy context}

In terms of research on multilingual education, Busch (2011) describes two shifting paradigms in Europe. First, a more sociolinguistic approach has been taken into consideration, which views schools from the perspective of a historical-critical analysis by emphasizing the school's social functions, criticizing its monolingual habitus, and advocating for an approach that relates teaching and learning practices to the specific social contexts. Moreover, the growing interest in bilingual or multilingual situations influences this. Second, in a more speaker-centered perspective, languages are no longer regarded as segmented, autonomous entities but rather, as holistic conceptions of plurilingual competences which are multiple, dynamic, integrated, contextualized, and individualized is used (Lüdi \& Py, 2009). 
Thus, access to different forms of multilingual education is increasingly seen as a necessary right for all learners, as it represents a resource on both the individual and societal levels (Lo Bianco, 2001).

This meta-analysis compares the development of the adjustments in European Union (EU) educational language policy based on the shifts described above in two European countries: Sweden, a EU member state since 1995, and Switzerland, one of the few countries in Western Europe that is not a member of the European Union but nevertheless adapts EU language policy recommendations like the "mother tongue plus 2" objective.

During the 2002 European Council in Barcelona, the Heads of State or Government of the EU called for at least two foreign languages to be taught from a very early age (European Commission, 2005). This eventually resulted in the policy objective, "Mother tongue plus two other languages," already described in the European Commission's action plan (European Commission, 2004). This usually means that English is one of the two other languages to be learned if English is not the mother tongue. For immigrants, the European Commission (2009) suggests that "Non-native speakers should therefore include the host-country language in their 'one-plus-two' combination."

Some noteworthy differences between Sweden and Switzerland are to be found in the two countries' political organization and their language history (including ideologies and policies). Given that "states typically license, authorize, fund, or certify educational practices" (Lo Bianco, 2008), differences in the political formation of states influence their educational systems and curricula. History in general "occupies an important position in most work in language policy and planning, whether at the micro-level of interpersonal communication or the macro-level of state formation" (Ricento, 2006, p. 129). From a historical-structural standpoint in language policy and planning, where "historical processes are linked with language policies that contribute to (or undermine) language-related hierarchies" (Tollefson, 2015, p. 141), it is therefore inevitable to take a closer look at the two countries' history and central concepts in a historical-structural analysis, such as power and hierarchy in the two selected contexts.

\section{Sweden}

Because Swedish is officially used by the Church and the State, Sweden appears to be unproblematically monolingual (Boyd, 2011). As Hult (2004, p. 181) writes, the country "might best be characterized as a multilingual polity with a monolingual image." He continues, stating that "the Swedish language has been, and still is, central in shaping what it means to be Swedish." This is a characteristic trademark of nation states that, according to Busch (2011, p.545), remain the major players 
in language and education policy. While trying to adapt education plans to the European requirements of multilingual education, the political discourse in many countries "foregrounds proficiency in the official national language(s) as exclusive means and as the proof of successful 'integration' into 'majority culture".' In respect to Sweden, Milani (2007) claims that a nation state experiencing an increased linguistic heterogeneity will also experience conflicting language ideologies as the people construct a new sociolinguistic landscape.

According to Andersson and Lundström (2010), the percentage of people who live in Sweden but were born outside of Sweden rose from about $11 \%$ in the year 2000 to about $14 \%$ in 2008. In 2015, the number had reached 17\% (Statistics Sweden, 2015). However, societal multilingualism is not only determined by the number of people immigrating to a country but also by the number of people born where the national language is not their mother tongue. According to Statistics Sweden, by 2015, 22.2\% of the inhabitants in Sweden had a foreign background. ${ }^{1}$ This heterogeneity has also had an impact on the education system and policy:

Society itself has changed rather dramatically during the last 10 years. Sweden is no longer a homogenate society with small differences between various groups and classes. Sweden is now a multicultural society, and class differences are increasing. These differences tend to effect variations within the education system. Variations or inequalities [...] in the education system are not necessarily effects of education reform; they could be the result of societal change.

(Wildt-Persson \& Rosengren, 2002, p. 318)

Sweden is no exception in terms of having a history of multilingualism, especially when one considers that the Sami and Finnish-speaking minorities have inhabited Sweden for a long time. If the Swedish empire of the late seventeenth century is taken into consideration, 14 different languages and many varieties show proof of a multilingual nation even then (Winsa, 2005). Nevertheless, the Swedish-speaking majority had never felt challenged in a way that language policy had to be made more overt until the 1990s, when the Swedish Language Council initiated the endeavor of developing a new language act. These shifts in Swedish language policy are well-described by Boyd and Huss (2001), who mainly focus on the relation of the Swedish language to English and other minority languages. Also, according to the recent analysis by Halonen, Ihalainen, and Saarinen (2015), given the presumed unproblematic monolingual nature of Sweden, language policy has become explicitly problematized at the governmental level only since the beginning of the twenty-first century.

1. People of foreign background are per definition born abroad or born in Sweden to two parents born abroad. 
Faced with the recognition of Swedish as an official and working language of EU institutions due to the accession of Sweden to the EU in 1995, and coupled with rising immigration and a further diversification of the linguistic landscape, an ambitious policy report entitled "Mål i mun" (SOU, 2002) was published by the parliamentary Committee on the Swedish Language. The document consists of nearly six hundred pages of proposals related to the promotion of the Swedish language. Nevertheless, it was only in the Language Act of 2009, in accordance with the language planning goals that were adopted in $2005^{2}$ ("Bästa språket - en samlad svensk språkpolitik," 2005/06:2), that Swedish was officially defined as the 'main language' of Swedish society as well as the language of administration. The new language law was the answer to an imbalance in terms of language rights. In 1999, Sweden ratified the Council of Europe Framework convention for the Protection of National Minorities and the European Charter of Regional and Minority Languages, by which Finnish, Sámi, Meänkieli, the Romani chib, and Yiddish maintained their status as minority languages (Lindberg, 2007). This meant that for some years, in contrast to the five minority languages, Swedish itself had no legally recognized status. While the minority languages' official status (see also Hult, 2004; Hyltenstam \& Milani, 2005) was confirmed, the Language Act was mainly about securing the development of Swedish, its constant use in international contexts, and the right of every inhabitant of the country to have access to learning the language (Halonen et al., 2015). This last aim can be viewed as an attempt at implementing the EU goal of the mastery of three languages (mother tongue plus two) mentioned earlier in this article (Norrby, 2008).

A special focus was placed on the relationship between Swedish and English in addition to the societal multilingualism due to almost 200 'immigrant' minority languages with no official status, although their speech communities far outnumber at least four of the five official minority languages. This is especially the case with English, ${ }^{3}$ which is widespread in many societal domains like culture, higher education, and internationally oriented companies and seen as a threat to Swedish. The following quotation is taken from the English version of the website of the Language Council of Sweden (Institutet för språk och folkminne, 2016):

2. There are four national language planning goals:

1. Swedish shall be the principal language of Sweden.

2. Swedish shall be a complete language in the sense that it shall function as a vehicle of communication in all areas of society.

3. Swedish in official and public use shall be correct but also simple and easy to understand.

4. Everyone has the right to languages - to Swedish, their mother tongue and foreign languages.

3. According to estimates, $75 \%$ of the Swedish adult population is able to read an English newspaper or manage an ordinary conversation (Josephson, 2003). 
During the last decades, English has started to compete with Swedish in a growing number of fields in Swedish society - in large, international companies, in the educational system and in the media industry. This poses a threat to democratic values as many Swedes have insufficient knowledge of English.

However, viewing English as a threat is only true for a limited circle of language professionals. English enjoys a good reputation with the rest of the population, while immigrant languages are regarded with suspicion and considered a threat to the Swedish language (Lindberg, 2007). According to Hyltenstam (1999), the strong presence of English in high-status domains might create a diglossic situation with Swedish being the low-status variant. People with limited or no English proficiency could be excluded from important and powerful social discussions and decisions. However, other experts claim that no research confirms a domainby-domain language shift (Boyd \& Dahl, 2006). Sundberg (2013, p. 212) states that the policy "attempts to 'protect' the Swedish language in a situation in which English is becoming too powerful in certain areas while at the same time recognizing its importance and supporting a balanced bilingualism by promoting parallel proficiencies in the two languages." Generally, these contrasting opinions are interesting when bearing in mind Tollefson's (2006, p.42) comparison of traditional research and a critical approach in language policy research. He states that "traditional research [...] is characterized by the assumption that language policies are usually adopted to solve problems of communication in multilingual settings and to increase social and economic opportunities for linguistic minorities" while "a critical approach acknowledges that policies often create and sustain various forms of social inequality, and that policy-makers usually promote the interests of dominant social groups."

According to Norrby (2008, p.73), the result of the most recent Swedish language politics is "societal monolingualism with Swedish being used for interaction in public life, whereas multiculturalism and multilingualism remain a question for the individual to pursue in private life." This indicates that in order to achieve the language policy objective of the European Union (mother tongue plus two), the majority population whose first language is Swedish has to do more than expected by the Swedish Language Act. Winsa (2005, p. 320) calls this development an assimilation policy with a nationalistic attitude, which is "a natural part of the Swedish monolingual identity, not one derived from a long tradition of language planning." In contrast to Winsa's statement, Hyltenstam, Axelsson, and Lindberg (2012) mention the tension in society between a pluralist ideology, established at the central political level since the 1960s (as is evinced by political documents) and an assimilationist perspective, which is strong in large segments of the population. 


\section{Switzerland}

In contrast to the Swedish case, Switzerland is known as the multilingual country par excellence. According to Secretary General Schwab of the Federal Assembly of the Swiss Confederation (2014), "plurilingualism is an integral part of Switzerland's identity and is a key element of the national culture. It is a result of the way in which the Confederation has developed historically." However, due to the federalist system of this central European country, or to use Kymlicka's (2011) term, "multination federalism," one can be cautious about the Swiss individual plurilingualism. Switzerland is used as an example of multiple, monolingually oriented school systems in a state with a multilingual composition (Busch, 2011) due to the strong territorial autonomy of the various linguistic groups. Therefore, in contrast to the Swedish nation state, it is common for Switzerland not to have a national curriculum.

Currently, around 33\% of the people living in Switzerland are not Swiss citizens (Bundesamt für Statistik, 2016b). This rather high percentage is the result of several factors: the bilateral agreement on the free movement of persons between the European Union and Switzerland, Switzerland's restrictive immigration policy, and the high birth rate and low death rate of the non-Swiss population. In a previous press release (Bundesamt für Statistik, 2015), it is stated that about a fifth of the foreign population in Switzerland was born in Switzerland, and half of those who were born abroad have been living in Switzerland for more than 10 years.

According to the latest statistics, $60 \%$ of all people living in Switzerland use more than one language at least once per week. Furthermore, $40 \%$ of all people living in Switzerland use English at least once per week (Bundesamt für Statistik, 2016a). Compared to the long history of a plurilingual and pluricultural aggregation of states known as cantons, plurilingualism was introduced rather late into the Federal Constitution of 1848 . Due to immigration and professional mobility, the diversity of languages in Switzerland has greatly increased.

In order to coordinate and optimize language teaching and learning in compulsory education, the Swiss conference of Cantonal Ministers of Education (EDK, Schweizerische Konferenz der kantonalen Erziehungsdirektion) adopted a national strategy of language teaching (EDK, 2004) primarily consisting of several general objectives, including the following:

4. Kymlicka's model of multinational federalism has two key features: (1) minority groups form local majorities and (2) minority groups have a distinct language which is typically an official state language.

5. Productively or receptively. 
- The reinforcement of the language of schooling

- The compulsory study of two foreign languages ${ }^{6}$ at primary school level and of another (national) language as an option from the ninth school year

- The development of the pupils' skills in their first language (if different from the language of schooling)

In 2007, a new Federal act (Sprachengesetz, 2007) aimed at promoting plurilingualism was introduced, and in 2010, a new article in the Federal Constitution of the Swiss Confederation (Schweizerische Eidgenossenschaft, 1999 (2016)) went into effect stating the following:

1. The official languages of the Confederation are German, French, and Italian. Romansh is also an official language of the Confederation when communicating with persons who speak Romansh.

2. The Cantons shall decide on their official languages. In order to preserve harmony between linguistic communities, the Cantons shall respect the traditional territorial distribution of languages and take into account the indigenous linguistic minorities.

3. The Confederation and the Cantons shall encourage understanding and exchange between the linguistic communities.

4. The Confederation shall support the plurilingual Cantons in the fulfillment of their special duties.

5. The Confederation shall support measures by the Cantons of Graubünden and Ticino to preserve and promote the Romansh and Italian languages.

In 2009, an agreement on the harmonization of compulsory education (EDK, 2007) between the cantons came into effect. This agreement is relevant to the topic because it asked for new multilingual educational policy documents covering the 2004 national strategy for language teaching and the new Federal act mentioned above. Due to the federalist nature of the country, educational curricula for foreign language instruction are a matter of the cantons and their affiliation to a linguistic region. Therefore, Switzerland currently knows three curricula, one for each large linguistic area: Le plan d'études romand, Lehrplan 21, and Il piano di studio per la scuola dellobbligo ticinese. The curriculum for the German speaking region of Switzerland consisted of different project curricula during the implementation period, resulting in foreign languages being taught in different orders in the Germanic area of the country, contradicting the intention of harmonization in educational policy.

6. In the Swiss educational system, all languages, including official national languages, are termed "foreign languages" if they are not the same as the schooling language of the corresponding region. 


\section{Methodology}

\section{Retrieval of studies}

To compile the literature for the systematic review, a comprehensive search for relevant articles was conducted, and as suggested by certain authors (see Hart, 1998; Machi, 2012), the articles were selected utilizing in a multiple step process. Many resources were accessed in order to locate appropriate information to substantiate this research study. The databases that were accessed for full-text resources ranged from Summon (the Malmö University library database/search engine application) to education databases such as the Education Research Information Center (ERIC) via EBSCO and the Linguistics and Language Behavior Abstract database (LLBA). In these online journal databases, the keywords "language policy" or "language planning" in combination with the respective country, "Sweden" or "Switzerland," were searched. The results provided a rich supply of literature that enabled reaching saturation for the meta-analysis. Because this study focuses on the latest developments in multilingual educational language policy, the results were narrowed down by only looking at research results between 2009-2016. The starting year of this time frame filter seemed fitting due to the introduction of the Language Act in Sweden and the agreement on the harmonization of compulsory education in Switzerland, which both took place in 2009.

\section{Inclusion and exclusion criteria}

Before the time frame filter was applied, a total of 339 hits for the Swedish context and 431 hits for the Swiss context were identified. The application of the filter substantially reduced the results to 99 hits for the Swedish context and 74 hits for the Swiss context. The abstracts of all the articles in these results were read and including and excluding factors were applied.

\section{Inclusion Criteria}

1. The study was published between 2009 and 2016 .

2. The study focused on language policy and/or planning.

3. The study was conducted in a mainstream mandatory educational setting in order to include a wide range of student performances.

4. The study focused either on Switzerland or Sweden.

\section{Exclusion Criteria}

1. The study was published earlier than 2009 .

2. The study addressed questions in non-educational settings. 
3. The study focused on issues regarding sign language with deaf pupils. Unfortunately, this research review is unable to cover the vast field of special education.

4. The study focused on multilingual policies in higher education.

5. The study did not address issues in Sweden or Switzerland.

Table 1. Search results for the Swedish context

\begin{tabular}{lllc}
\hline Database & Keywords & Filter & Hits \\
\hline ERIC (Educational Resources Information Center) & Sweden, language & - & 40 \\
via EBSCOhost & policy & $2009-2016$ & 17 \\
ERIC (Educational Resources Information Center) & Sweden, language & - & 31 \\
via EBSCOhost & planning & $2009-2016$ & 10 \\
LLBA (Linguistics and Language Behavior Abstract) & Sweden, language & - & 147 \\
& policy & $2009-2016$ & 48 \\
LLBA (Linguistics and Language Behavior Abstract) & Sweden, language & - & 121 \\
& planning & $2009-2016$ & 24 \\
\hline
\end{tabular}

Table 2. Search results for the Swiss context

\begin{tabular}{lllr}
\hline Database & Keywords & Filter & Hits \\
\hline $\begin{array}{l}\text { ERIC (Educational Resources Information Center) } \\
\text { via EBSCOhost }\end{array}$ & $\begin{array}{l}\text { Switzerland, language } \\
\text { policy }\end{array}$ & - & 28 \\
ERIC (Educational Resources Information Center) & Switzerland, language & - & 5 \\
via EBSCOhost & planning & $2009-2016$ & 5 \\
LLBA (Linguistics and Language Behavior & Switzerland, language & - & 4 \\
Abstract) & policy & $2009-2016$ & 34 \\
LLBA (Linguistics and Language Behavior & Switzerland, language & - & 200 \\
Abstract) & planning & $2009-2016$ & 31 \\
\hline
\end{tabular}

The identified articles were exported and organized in the reference system program, EndNote. In order to analyze the articles, they were illustrated in a chart containing information about the research aim and questions, the theoretical framework, and the methodology for each study. Moreover, the results of the studies were noted. To answer the second research question of the meta-analysis and make visible similarities and differences in Swiss and Swedish research results, the identified studies were then analyzed according to the predominant topics discussed in the articles. 


\section{Results}

This study aims to illustrate and compare the predominant foci in research results on Swiss and Swedish educational language policy. As a first step, the identified articles from both contexts are listed below.

\section{Identified articles}

For the Swedish context, a total of nine articles fit the inclusion criteria and were selected for this meta-analysis:

- Cabau (2009a). The Irresistible Rise and Hegemony of a Linguistic Fortress: English Teaching in Sweden.

- Cabau (2009b). Language-in-Education Policy and Planning in Sweden.

- Wedin (2010). A restricted curriculum for second language learners - a selffulfilling teacher strategy?

- Hult (2012). English as a Transcultural Language in Swedish Policy and Practice.

- Tholin (2012). If you get double the time: Teaching practices in the "Swedish/ English" language subject option in Swedish nine-year compulsory schooling.

- Björklund, Björklund, and Sjöholm (2013). Multilingual Policies and Multilingual Education in the Nordic Countries.

- Bolton and Meierkord (2013). English in contemporary Sweden.

- Amir and Musk (2014). Pupils doing Language Policy: Micro-interactional insights from the English as a foreign language classroom.

- Cabau (2014). Minority Language Education Policy and Planning in Sweden.

Four articles matched all the inclusion criteria for the Swiss context and were thus selected for this meta-analysis.

- Stotz, Bossart, and Fischli (2009). Learning Languages at School in the Interplay of Society and Identity.

- Haenni Hoti (2009). Research Results on Factors Influencing Elementary School Students' English Skill, with Special Attention to Immigration Background.

- Heinzmann (2010). Has the Introduction of "Early English" in Primary School Had an Influence on Primary School Students' Motivation to Learn French?

- Daryai-Hansen et al. (2015). Pluralistic approaches to languages in the curriculum: the case of French-speaking Switzerland, Spain and Austria. 
While all the articles for the Swedish context were written in English, three out of four for the Swiss context were published in German, indicating a smaller target group for their research results. An interesting difference between the two countries' research results is the missing focus on national language policy and approach to language learning in Switzerland. More than half of the Swedish research projects included a discussion on this topic. A probable explanation for this characteristic could be the introduction of the new Swedish Language Act in 2009, which according to Bolton and Meierkord (2013, p. 111), is the culmination of "successive moves towards nationally-oriented language polices [motivated] by covert concerns about immigration and the changing ethnic profile of Swedish society." A similar discussion in Switzerland could not be identified.

Table 3. Research focus ${ }^{*}$ of the included studies

\begin{tabular}{lll}
\hline Research focus & Sweden & Switzerland \\
\hline National language policy & 5 & 0 \\
Curriculum/syllabus & 5 & 2 \\
Role of the teachers & 1 & 1 \\
Role of the pupils & 1 & 2 \\
\hline
\end{tabular}

* Due to studies where there were more than one research focus identified, the total number of foci are greater than the number studies $(N=13)$ included in the meta-analysis.

With regard to content, four different topics could be identified for the comparison of the Swiss and the Swedish context. First, the articles show different degrees of awareness of plurilingual pupils. Then the subject of the second foreign language is greatly discussed in several articles. Moreover, the English language and its role in society and the educational arena can be classified as an important topic for this meta-analysis. Last, but not least, is the gap between language policy and language planning - a common topic found in the results for Swiss and Swedish educational policy research. These four topics provide the foundation to answer the second research question about a possible monolingual or pluralistic approach in the treatment of educational language policies.

\section{Awareness of plurilingualism}

Björklund et al. (2013, p. 12) report that the school curricula in most Nordic countries are based on monolingual assumptions. As a consequence of this "monolingual and - cultural bias," language students tend to be treated from the perspective of the language of the school rather than from the perspective of their individual plurilingualism. This research result is much in line with Goglin's concept of 
the monolingual habitus mentioned earlier and stands in conflict with ecologi$\mathrm{cal} /$ holistic theories of language teaching that are, for instance, an integrated part of Swiss curricula, as Daryai-Hansen et al. (2015) show. Their aim is to illustrate and discuss how the development of plurilingual competences is implemented in some European countries, including French-speaking Switzerland with its new curriculum. To do so, the authors analyzed the curriculum according the Framework of Reference for Pluralistic Approaches to Languages and Cultures FREPA (Candelier et al., 2012), and therefore, in terms of which languages ${ }^{7}$ and pluralistic approaches ${ }^{8}$ that were integrated and to what extent the transversal dimension of learning to learn is part of the curriculum. Moreover, they discuss barriers and challenges to overcome for plurilingualism to become the standard for all pupils.

As Daryai-Hansen et al. (2015, p.113) found out, in the new curriculum for compulsory education in French-speaking Switzerland, the Plan détudes romand, all languages are grouped in one domain, so as to aim at the "integrated development of languages, French as the language of schooling, and German (L2) and English (L3) as foreign languages" (CIIP, 2010) and to foster "the development of a plurilingual repertoire, in which all linguistic competences are included - L1, L2, L3 - and other languages, such as the first languages of bi- or trilingual students in particular, can find their place." Daryai-Hansen and her colleagues therefore conclude that the curriculum "is consistent with the concept of plurilingualism as promoted by the Council of Europe" (p. 113).

Although the results by Björklund et al. (2013) might point to a lack of awareness of plurilingual pupils in the Swedish context, other research results show the opposite. However, this awareness might lead to a restricted curriculum for second-language learners as examined by Wedin (2010). She studies the relations between second language development and subject learning among L2 learners by conducting a longitudinal study (3.5 years) in two primary school classes. Wedin comes to the conclusion that L2 learners are often offered a restricted curriculum with low-demanding tasks. Creating this safety zone for students is the equivalent of a self-fulfilling prophecy, and therefore, mean limited opportunities for school success. According to Wedin, it is crucial that all students (L1 and L2 students) are "involved in interactions using both the specific and the reflexive registers early on in schooling to enable them to meet the demands of later years of schooling" (2010, p. 181). Wedin concludes with a demand for a more reflexive and critical

7. Language of schooling, regional, minority and migration languages, modern and classic foreign languages or linguistic varieties, registers, styles, and genres.

8. Integrated didactic approach, intercomprehension, Éveil aux langues/Awakening to languages approach 
approach by teachers in how language is used in the classrooms and the possibility to use other languages mastered by students in the class as a resource.

The same negative misconception of pupils' plurilingualism can also be found in the Swiss context and is touched upon in the study by Haenni Hoti (2009). The first aspect of her study analyzes the effectiveness of learning an L2 (English) and an L3 (French) in primary school, which is a direct consequence of the harmonization agreement and its new curriculum. The second aspect examines the influence of the pupils' migratory background and (bi)national identification. The results of the study are multifaceted and show, among other things, that binational and bicultural identification seems to be a marker for significant better results. Therefore, the author suggests uncoupling binationality and overstraining, and instead, focus on individualizing and differentiating in the classroom.

Another study from the Swiss context advocates generalizing less about the attitude towards pupils' plurilingualism in one political country. The two case studies described in the article by Stotz et al. (2009) show different stereotypes of plurilinguals held by teachers in different societal contexts. The notion of the monolingual habitus cannot only be based on the political format of the country, but also the local circumstances. This result is of special interest as the two contexts are both located in the same linguistic area of Switzerland.

In addition, the fourth article for the Swiss context shows a high awareness of plurilingualism, mentioning the curriculum's didactics of multilingualism and its national educational objective of functional plurilingualism for all pupils. A study by Heinzmann (2010) investigates the possible motivational effects of the learning of first foreign language (in this case, English) on the learning of the second foreign language (French). She concludes that English teachers may not yet be adequately aware of how much their focus on multilingualism and other cultures might positively influence the further study of the foreign languages of all pupils.

\section{Third language acquisition}

The teaching and learning of a third language is highly prominent in both policy contexts under scrutiny. However, their orientation could not be more diverse. While Swiss research focuses on the effectiveness of the first foreign language on the second foreign language (Haenni Hoti, 2009; Heinzmann, 2010) and discusses the newly mandatory subject of the second foreign language for all pupils ${ }^{9}$ as an addition to a more pluralistic teaching and learning (Daryai-Hansen et al.,

9. Prior to the new curriculum, learning a second foreign language was only mandatory for the stronger pupils. 
2015; Stotz et al., 2009), the concept of the freedom of choice is ubiquitous in the Swedish results.

In 1992, a Swedish government bill discussed the students' responsibility to choose a language study option. This neoliberal shift from state responsibility to individual responsibility (Cabau, 2009b, p. 386) was established when a new curriculum was introduced two years later and did not undergo a modification after the Language Act of 2009 in the curriculum introduced in 2011. As Tholin (2012, p.72) describes it in detail, instead of choosing an additional language like French, Spanish, or German and thereby fulfilling the European Union's objective of 'mother tongue plus two, "a great many students did not want to or could not study an additional language." However, they did opt for more lessons in Swedish, Swedish as a Second Language, English, or their mother tongue.

In her articles, Cabau (2009a, 2009b, 2014) describes the language option as a crisis for second language ${ }^{10}$ and mother tongue teachers because the interest in learning these languages is declining due to the general public's conviction that it is too demanding, too time-consuming, and not really necessary to be proficient in another language than Swedish (for national issues) and English (for international issues).

The topic of third language acquisition is closely linked to the position of the English language in the two countries.

\section{English}

Three of nine articles for the Swedish context mainly focus on the position of English. Hult (2012) investigates how discourses about English and multilingualism are framed in Swedish national educational policy and how educators make sense of these discourses. He employs an ethnographic and discourse analytic approach when analyzing the text of Sweden's national syllabi for language education as well as the interpretations of pre-service English language teachers. The data analysis is guided by the methodology of nexus analysis, connecting the languages policy texts and the individuals who negotiate policy discourses through their lived experiences as educators implanting policy in practice. Hult comes to the conclusion that the status of the English language in Sweden is still undergoing a dynamic process of transculturation in which the local position of English continues to be negotiated. According to his study, English is considered neither a second nor a foreign language in Sweden, but rather a transcultural language. Clearly, in Swedish policy texts, English is treated differently than other modern languages

10. In this case, the term second language includes the learning of all foreign languages. 
indicating that it has a different position in the linguistic hierarchy (Josephson, 2004) of the Scandinavian country.

Hult's stand on the topic is supported by Cabau (2009a, p. 140), who states that "English knowledge seems to be part of the (young) Swedes' cultural and linguistic identity." At the same time, Cabau (2014) describes the position of English as a hindering factor in the development of the linguistic diversity in the Swedish school context.

As described above (2. Sociolinguistic and policy context) the position of English in Sweden is often used as the explanation for the Language Act introduced in 2009. However, Bolton and Meierkord (2013) propose an alternative explanation and refer to Rojas (2005) and the new realities of a multiculturally diverse society which are "very different from the earlier ideal of the Social Democratic folkhemmet ('The People's Home')". A cross-relation to the earlier discussed individual plurilingualism of the pupils can be made at this point.

The third article from the Swedish context focusing on English has a slightly different orientation. Amir and Musk (2014, p. 106) examine language policing as the pupils' "corrective act to rectify what they perceive as talk by others in the 'wrong' medium in accordance with the normatively prescribed medium of instruction." Trying to construct this monolingual classroom is a sign of the absence of a pluralistic approach to language learning.

In the Swiss context, the position of English is also lively discussed; however, the core of the discussion is different. Stotz et al. (2009) focus on the adapted order of foreign languages instructed in Swiss school due to the 2009 agreement on the harmonization of compulsory education in Switzerland. The agreement recommended French as a first foreign language in German-speaking cantons, mainly due to its status as an official language of the country; however, two Germanspeaking cantons chose English. In the first part of the article, the results of critical discourse analyses of more than 100 policy and planning documents, meeting minutes, and media reports illustrate the legitimation of the prioritization in the order of foreign languages taught in the region under scrutiny. Stotz et al. (2009) report that the pillars of legitimation were transformed several times during the implementation process, and Haenni Hoti (2009) and Heinzmann (2010) each examine the interrelation of English and French language learning.

Discrepancy between language policy and language planning

Research results in both contexts locate a substantial discrepancy between policy and planning. Daryai-Hansen et al. (2015) state that plurilingual competence is not established in education in general, instead separate plurilingualism, consisting of pure and separate languages is a widespread ideology in educational 
practices. The main concern of the study by Cabau (2014) was the gap between language-in-education policy and planning for minority languages in Sweden. She investigated the various challenges facing mother tongue teaching and the impact of the introduction of a national language policy. The conclusion of her discursive contextual analysis is the mismatch of the principles of equity in education and uniformity at compulsory Swedish schools with the objective of bilingualism for minority children. She also concludes that "it is not so much the languages that need to be valued, but the richness of human resources represented in Swedish society" (Cabau, 2014, p.422). Hence, the author demands the acknowledgment of knowing a minority language outside the school arena that is in higher education and professional development. This could solve the problem of status, which interferes with the existing mother tongue teaching opportunities in Sweden, where pupils are reluctant to enroll in these courses because of the low status of their heritage language in Swedish society.

Tholin (2012, p. 87) uses different dimensions of a curriculum (Goodson, 1995) to explain the discrepancy between the curriculum and the pupils' choices in terms of their language study options:

The ideological curriculum with the idea that all, or almost all, students should study an additional foreign language, the formal curriculum in which $S v E n^{11}$ is offered as an alternative without appearing as an equivalent to the foreign languages, and the understood curriculum in which SvEn is the alternative that most students choose. Schools, students, and parents did not perceive a 'soft compulsoriness', as a quarter of the students do not study foreign languages.

As a final result for this factor, it needs to be added that the actual implementation of multilingual educational language policies is not guaranteed even with the availability of a curriculum with a focus on interlinguistic approaches. DaryaiHansen et al. (2015, p.115) remind the reader that actual implementation "will certainly take time and necessitate further training and coordination (both horizontal and vertical) at a more local level."

\section{Conclusions}

The meta-analysis clearly shows different approaches toward multilingual educational policy applied in Sweden and Switzerland. While the Swedish context focuses more on specific subjects that fulfill a role in the development of a mul-

11. This is the most common term for the language option of more lessons in Swedish or English. (Tholin, 2012, p. 72) 
tilingual repertoire, research in Switzerland applies a more holistic view of multilingualism (interrelations of language subjects). This conclusion can be explained by the different approaches in the curricula in the two countries. The Swiss curricula all include a holistic approach toward language teaching which fosters separate plurilingualism, whereas the Swedish one does not. Therefore, it is not surprising to see that the research results in these two contexts differ along the same line. For a more detailed meta-analysis on this topic, curriculum and syllabi could have been added as keywords in the search process. Based on the discussion on shifting paradigms in language teaching, the Swiss context seems to be closer to the current state of the art. Given that educators in Sweden are encouraged to interpret national curricula directly (Hult, 2014), some kind of further education for teachers or input by the Swedish Schools Inspectorate could advance their understanding of pluralistic approaches to language teaching.

The different outcomes of the research results search might, to a considerable degree, be due to the various understanding of the terms multilingualism and plurilingual student. Three out of four articles from the Swiss context focusing on multilingual educational policies include all students and not only those with a mother tongue other than that of the local language. Therefore, it can be concluded that students in Switzerland are considered to be plurilingual as soon as they have gained knowledge of more than one language, disregarding whether one is the language of a parent or the first foreign language instructed in school. This understanding is also portrayed in the current Swiss curriculum. In contrast, in Sweden, discourses of plurilingual students often refer to those children with a migratory background and another mother tongue than Swedish thus discriminating them as different. Generally, finding a definition of multilingualism is a challenging task. Even among scholars, there does not appear to be any agreement. While Jessner (2008, p.20) writes that the "monolingual perspective of multilingualism is still prevalent in traditional research on language acquisition," this meta-analysis is able to show a stronger monolingual habitus in the Swedish nation state perception than in Switzerland.

An intriguing aspect is the position of English in the two countries' research results. While the English language is present in both contexts, it receives much more attention in Sweden. Articles by Cabau (2009b), and Hult (2012) in particular, discuss the position of English in the Swedish linguistic hierarchy and its role as a factor in the hindrance of the development of linguistic diversity in the Swedish educational arena. In the Swiss research results, English is only mentioned as a positive aspect of linguistic diversity.

The Swiss context provides pluralistic approaches in the curriculum, while the Swedish curriculum is still based on the assumption of monolingualism as the norm (Björklund et al., 2013). Moreover, as mentioned, the definition of plurilin- 
gual students in Switzerland includes all pupils, making multilingual educational language policy an affair of everyone. However, despite these approaches and understandings, both countries struggle during the implementation process. It seems as the teachers as the last social scale where policies become action (Hult, 2014) are similarly difficult to convince of state-of-art multilingual language policy in both countries, indicating an underlying language policy and planning effect regardless of the differences in the political and/or linguistic conditions of a country.

In general, in is important to note that little research is internationally published on the multilingual educational language policies of Sweden and Switzerland. The varying definitions of plurilingual pupils and how they influence the implementation of multilingual educational language policies is certainly an interesting topic to examine further. Thus, given that the implementation process of the new curriculum in Switzerland began only a few years ago, it is suggested that more research be conducted in Switzerland in a few years to examine the outcome of this new approach in language teaching.

\section{References}

Amir, A., \& Musk, N. (2014). Pupils doing language policy: Micro-interactional insights from the English as a foreign language classroom. Apples - Applied Language Studies, 8(2), 93-113.

Andersson, J., \& Lundström, K.E. (2010). Arbetsmarknad och integration. Stockholm: Svenskt Näringsliv/Sveriges Akademikers centralorganisation.

Bästa språket - en samlad svensk språkpolitik, (2005/06:2).

Björklund, M., Björklund, S., \& Sjöholm, K. (2013). Multilingual policies and multilingual education in the Nordic Ccountries. International Electronic Journal of Elementary Education, 6(1), 1-22.

Bolton, K., \& Meierkord, C. (2013). English in contemporary Sweden: Perceptions, policies, and narrated practices. Journal of Sociolinguistics, 17(1), 93-117. https://doi.org/10.1111/josl.12014

Boyd, S. (2011). Do national languages need support and protection in legislation? The case of Swedish as the 'principle langague' in Sweden. In C. Norrby and J. Hajek (Eds.), Uniformity and diversity in language policy (pp. 22-25). Bristol: Multilingual Matters.

Boyd, S., \& Dahl, Ö. (2006). Grundlöst om språkdöd. Språkvård, 4, 36-40.

Boyd, S., \& Huss, L. (2001). Managing multilingualism in a European nation-state: Challenges for Sweden. Clevedon: Multilingual Matters.

Bundesamt für Statistik, B. (2015). Wanderungssaldo sinkt leicht gegenüber 2013 [Press release]

Bundesamt für Statistik, B. (2016a). Sprachliche Praktiken in der Schweiz Erste Ergebnisse der Erhebung zur Sprache, Religion und Kultur 2014. Retrieved from Neuchâtel: 
Bundesamt für Statistik, B. (2016b). Ständige Wohnbevölkerung. Retrieved 9 February 2016 from http://www.bfs.admin.ch/bfs/portal/de/index/themen/01/01/new/ nip_detail.html?gnpID=2016-559

Busch, B. (2011). Trends and innovative practices in multilingual education in Europe: An overview. International Review of Education, 57(5-6), 541-549. https://doi.org/10.1007/s11159-011-9257-1

Cabau, B. (2009a). The irresistible rise and hegemony of a linguistic fortress: English teaching in Sweden. International Multilingual Research Journal, 3(2), 134-152. https://doi.org/10.1080/19313150903073786

Cabau, B. (2009b). Language-in-education issues: Sweden as a case study. Educational Studies, 35(4), 379-389. https://doi.org/10.1080/03055690802648366

Cabau, B. (2014). Minority language education policy and planning in Sweden. Current Issues in Language Planning, 15(4), 409-425. https://doi.org/10.1080/14664208.2014.927086

Candelier, M., de Pietro, J. -F., R. Facciol, I. Lőrincz, X. Pascual, and A. Schröder-Sura. (2012). FREPA - A Framework of Reference for Pluralistic Approaches to Languages and Cultures Competences and resources Retrieved 13 February 2016 from http://carap.ecml.at

CIIP. (2010). Plan d'études romand. Retrieved 14 February 2016 from http://www.plandetudes.ch

Daryai-Hansen, P., Gerber, B., Lörincz, I., Haller, M., Ivanova, O., Krumm, H. -J., \& Reich, H.H. (2015). Pluralistic approaches to languages in the curriculum: The case of French-speaking Switzerland, Spain and Austria. International Journal of Multilingualism, 12(1), 109-127. https://doi.org/10.1080/14790718.2014.948877

European Commission. (2004). Promoting language learning and linguistic diversity. An action plan 2004-2006. Retrieved from Luxembourg: Luxembourg.

European Commission. (2005). A new framework strategy for multilingualism. Retrieved from Brussles: CoEC:

European Commission. (2009). Multilingualism: An asset for Europe and a shared commitment. Retrieved from Brussles: CoEC:

Gogolin, I. (2013). The "monolingual habitus" as the common feature in teaching in the language of the majority in different countries. Per Linguam: A Journal of Language Learning, 2, 38-49.

Gogolin, I., \& Duarte, J. (2013). Linguistic superdiversity in urban areas: Research approaches. Amsterdam: John Benjamins.

Goodson, I. (1995). Making of curriculum: Collected essays (2nd ed.). London: Falmer.

Haenni Hoti, A. (2009). Research results on factors influencing elementary school students' English skills, with special attention to immigration background. [Forschungsergebnisse zu Einflussfaktoren auf die Englischfertigkeiten von Primarschulerinnen unter besonderer Berucksichtigung des Migrationshintergrunds]. Bulletin suisse de linguistique appliquee, 89(Spring), 5-14.

Halonen, M., Ihalainen, P., \& Saarinen, T. (2015). Language policies in Finland and Sweden: Interdisciplinary and multi-sited comparisons. Bristol: Multilingual Matters.

Hart, C. (1998). Doing a literature review: Releasing the social science research imagination. London: SAGE, in association with The Open University. 
Heinzmann, S. (2010). Has the introduction of "early English" in primary school Hhad an influence on primary school students' motivation to learn French? [Hat die Einfuhrung von 'Fruhenglisch' in der Primarschule einen Einfluss auf die Motivation der Primarschulkinder Franzosisch zu lernen?]. Bulletin suisse de linguistique appliquee, 91(Summer), 7-27.

Hult, F. M. (2004). Planning for multilingualism and minority language rights in Sweden. Language Policy, 3(2), 181-201. https://doi.org/10.1023/B:LPOL.0000036182.40797.23

Hult, F. M. (2012). English as a transcultural language in Swedish policy and practice. TESOL Quarterly: A Journal for Teachers of English to Speakers of Other Languages and of Standard English as a Second Dialect, 46(2), 230-257. https://doi.org/10.1002/tesq.19

Hult, F. M. (2014). How does policy influence language in education? In R. E. Silver \& S. M. Lwin (Eds.), Language in education: Social implications (pp. 159-175). London: Continuum.

Hyltenstam, K. (1999). Sveriges sju inhemska språk: ett minoritetsspråksperspektiv. Lund: Studentlitteratur.

Interkantonale Vereinbarung über die Harmonisierung der obligatorischen Schule (HarmoS-Konkordat), (2007).

Hyltenstam, K., Axelsson, M., \& Lindberg, I. (2012). Flerspråkighet - en forskningsöversikt. Stockholm: Vetenskapsrådet rapportserie.

Hyltenstam, K., \& Milani, T.M. (2005). Nationella minoriteter och minoritetsspråk. Uppföljning av Sveriges efterlevnad av Europarådets konventioner på nationell nivå: ett minoritetsspråksperspektiv. In Konstitutionsutskottet (Ed.), Nationella minoriteter och minoritetsspråk (pp. 23-74). Stockholm: Sveriges riksdag.

Institutet för språk och folkminne. (2016). Welcome to the Language Council of Sweden - the official language cultivation body of Sweden. Retrieved 28 November 2016 from http://www.sprakochfolkminnen.se/om-oss/kontakt/sprakradet/om-sprakradet/inenglish.html

Jessner, U. (2008). Teaching third languages: Findings trends and challenges. Language Teaching, 41(1), 15-56. https://doi.org/10.1017/S0261444807004739

Josephson, O. (2003, 2016-02-01). Sweden on the threshold to multilingualism - a new Swedish language policy. Retrieved 1 February 2016 from http://www.efnil.org/conferences/archives/stockholm-2003/speeches/josephson-svenska

Josephson, O. (2004). Ju: ifrågasatta självklarheter om svenskan, engelskan och alla andra språk i Sverige: Stockholm: Norstedts akademiska förlag.

Kymlicka, W. (2011). Multicultural citizenship within multination states. Ethnicities, 11(3), 281-302. https://doi.org/10.1177/1468796811407813

Lindberg, I. (2007). Multilingual Education: a Swedish Perspective. In M. Carlson, A. Rabo, and F. Gök (Eds.), Education in 'multicultural' societies: Turkish and Swedish perspectives. London.

Lo Bianco, J. (2001). Language and literacy policy in Scotland. Retrieved 20 November 2016 from Stirling:

http://www.scilt.org.uk/Portals/24/Library/publications/languageandliteracy/Languagean dliteracypolicyinScotland_fulldocument.pdf

Lo Bianco, J. (2008). Educational linguistics and education systems. In B. Spolsky and F. M. Hult (Eds.), The Handbook of educational linguistics (pp. 113-126). Oxford and Boston: Blackwell. https://doi.org/10.1002/9780470694138.ch9 
Lo Bianco, J., \& Bal, A. (2016). Learning from difference. Cham: Springer International Publishing. https://doi.org/10.1007/978-3-319-26880-4_11

Lüdi, G., \& Py, B. (2009). To be or not to be ... a plurilingual speaker. International Journal of Multilingualism, 6(2), 154-167. https://doi.org/10.1080/14790710902846715

Machi, L.A. (2012). The literature review: six steps to success. Thousand Oaks, Calif: Corwin Press.

Milani, T. M. (2007). Debating Swedish: Language politics and ideology in contemporary Sweden. Stockholm: Stockholm University.

Norrby, C. (2008). Swedish language policy: Multilingual paradise or utopian dream? In J. Warren and H.M. Benbow (Eds.), Multilingual Europe: Reflections on language and identity (pp. 63-76). Newcastle upon Tyne: Cambridge Scholars Publishing.

OECD. (2017). Better Life Index. Retrieved 2 February 2017 from http://www.oecdbetterlifeindex.org

Ricento, T. (2006). An introduction to language policy: theory and method. Malden, MA: Blackwell Pub.

Rojas, M. (2005). Sweden after the Swedish model: From tutorial state to enabling state Retrieved from http://timbro.se/bokhandel/pdf/9175665891.pdf

Schwab, P. (2014). The Swiss parliament as a plurilingual forum. Retrieved from Bern: Bundesverfassung der Schweizerischen Eidgenossenschaft, (1999 (2016)). Mål i mun. Draft action programme for the Swedish language, (2002). Bundesgesetz über die Landessprachen und die Verständigung zwischen den Sprachgemeinschaften, (2007).

Sprachenunterricht in der obligatorischen Schule: Strategie der EDK und Arbeitsplan für die Gesamtschweizerische Koordination, (2004).

Statistics Sweden. (2015). People born outside of Sweden. Retrieved 2 February 2017 from http://www.scb.se

Stotz, D., Bossart, M. -N., \& Fischli, P. (2009). Learning languages at school in the interplay of society and identity. [Schulisches Sprachenlernen im Wechselspiel von Gesellschaft und Identitat]. Bulletin suisse de linguistique appliquee, 89(Spring), 41-59.

Sundberg, G. (2013). Language policy and multilingual identity in Sweden through the lens of Generation Y. Scandinavian Studies, 85(2), 205-232. https://doi.org/10.1353/scd.2013.0018

Swedish Ministry of Culture. (2009:600). Language Act (2009:600).

Tholin, J. (2012). If you get double the time: Teaching practices in the "Swedish/English" language subject option in Swedish nine-year compulsory schooling. Apples - Applied Language Studies, 6(1), 69-91.

Tollefson, J. W. (2006). Critical theory in language policy. In T. Ricento (Ed.), An introduction to language policy: Theory and method (pp. 42-59). Malden, MA: Blackwell Pub.

Tollefson, J. W. (2015). Historical-structural analysis. In F. M. Hult and D. C. Johnson (Eds.), Research methods in language policy and planning: A practical guide (pp. 140-151). Hoboken, NJ: Wiley-Blackwell.

Vertovec, S. (2007). Super-diversity and its implications. Ethnic and Racial Studies, 30(6), 1024-1054. https://doi.org/10.1080/01419870701599465

Wedin, A. (2010). A restricted curriculum for second language learners - a self-fulfilling teacher strategy? Language and Education, 24(3), 171-183.

https://doi.org/10.1080/09500780903026352 
Wildt-Persson, A., \& Rosengren, G. P. (2002). Equity and equivalence in the Swedish school system. In W. Hutmacher (Ed.), In pursuit of equity in education: Using international indicators to compare equity policies (pp. 299-321). London: Kluwer Academic Publishers. https://doi.org/10.1007/0-306-47579-0_14

Winsa, B. (2005). Language planning in Sweden. In R. B. Kaplan and R. B. Baldauf (Eds.), Language planning and policy in Europe: Vol. 1, Hungary, Finland and Sweden (pp. 233-330). Clevedon: Multilingual Matters.

\section{Mehrsprachige Sprach- und Sprachenpolitik in der schweizerischen und schwedischen Bildung: Eine Meta-Analyse}

\section{Zusammenfassung}

Mehrsprachigkeit ist eine globale Herausforderung und ein Bildungsziel europäischer Staaten. Diese Meta-Analyse untersucht, wie sich die Resultate von Forschungsprojekten über mehrsprachige Sprach- und Sprachenpolitik in der schweizerischen und der schwedischen Bildung auf einer Makroebene (national/regional) unterscheiden. Beschrieben werden die unterschiedlichen Schwerpunkte und Handhabungen von Diskursen in den jeweiligen Artikeln. Die Länder wurden aufgrund ihrer Ähnlichkeit in Bezug auf den gesellschaftlichen Kontext und ihrer Unterscheidung betreffend der Sprach- und Sprachenpolitik und der politischen Entstehung des jeweiligen Landes ausgewählt. Die Artikel wurden systematisch via zwei Datenbasen, ERIC und LLBA identifiziert und um die jüngsten Entwicklungen nach der Einführung des neuen Sprachgesetzes in Schweden und der Harmonisierung der öffentlichen Schule in der Schweiz 2009 zu erfassen, wurden nur Forschungsprojekte einbezogen, welche zwischen 2009 und 2016 publiziert wurden. Die Resultate der vorliegenden Meta-analyse weisen auf einen monolingualen Habitus im schwedischen Nationalstaat und einer eher pluralistischen Herangehensweise in der Schweiz hin. Ein nennenswertes Resultat ist die unterschiedliche Definition von Mehrsprachigkeit und mehrsprachigen Schülerinnen und Schülern und wie dieses Verständnis die Betrachtung von bildungspolitischen Steuerdokumenten in den zwei sprachliche und kulturell vielfältigen europäischen Ländern beeinflusst.

\section{Multlingvaj edukaj politikoj en Svislando kaj Svedio: Meta-analizo}

\section{Resumo}

Multlingvismo prezentas tutmondan defion kaj edukan celon en eŭropaj ŝtatoj. La nuna metaanalizo ekzamenas kiel esplorstudoj de dokumentoj pri multlingva eduka politiko je makronivelo (nacia/regiona) en Svedio kaj Svislando malsamas rilate fokusopunktojn kaj kiel la diskursoj en la esploroj reprezentas malsamajn pritraktojn de multlingvaj edukaj lingvopolitikoj. Oni selektis tiujn ĉi landojn pro iliaj similecoj de socia kunteksto, sed ili malsamas rilate lingvopolitikajn demandojn kaj politika formiĝo. La ekzamenita esplora literaturo estis sisteme identigita pere de du datenbazoj, ERIC kaj LLBA, kaj, por ekzameni la plej lastajn evoluojn post enkonduko de la nova lingvoleĝo en Svedio kaj la harmoniigo de publika edukado en Svislando 
en 2009, nur esplorartikoloj publikigitaj inter la jaroj 2009 kaj 2016 estis inkluzivitaj. La rezultoj de la studo sugestas, ke unulingva habitus ekzistas en la kunteksto de la sveda naciŝtato kompare kun pli pluralisma aliro en Svislando. La plej notinda rezulto estas la diverĝaj difinoj de multlingvismo kaj plurlingvaj studentoj kaj la maniero laŭ kiu tiu kompreno influas la traktadon de edukaj politikoj en tiuj du lingve kaj kulture superdiversaj eŭropaj landoj.

\section{Address for correspondence}

Adrian Lundberg

Faculty of Education and Society, Department of School Development and Leadership

Malmö University

20506 Malmö

Sweden

Adrian.lundberg@mau.se

\section{Biographical notes}

Adrian Lundberg is a Ph.D. candidate in pedagogy at Malmö University, Sweden. His current research focuses on language policy and multilingualism in the Nordic countries and Switzerland. 